Biol. Stud. 2019: 13(1); 39-50 • DOI: https://doi.org/10.30970/sbi.1301.587

www.http://publications.Inu.edu.ua/journals/index.php/biology

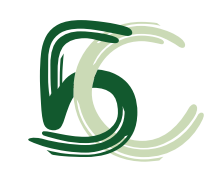

UDC: 616.697:612.616.2

\title{
THE RELATIONSHIPS BETWEEN CHANGES IN MAIN BIOCHEMICAL PARAMETERS IN SPERM CELLS OF INFERTILE MEN
}

\author{
R. V. Fafula, Z. D. Vorobets \\ Danylo Halytsky Lviv National Medical University, 69, Pekarska St., Lviv 79010, Ukraine \\ e-mail:roman_fafula@ukr.net
}

Fafula R.V., Vorobets Z.D. The relationships between changes in main biochemical parameters in sperm cells of infertile men. Studia Biologica, 2019: 13(1); 39-50 • DOI: https://doi.org/10.30970/ sbi.1301.587

Detection of the regularities of functions of male genital cells, playing a principal role in the reproductive realization (environmental and psychological stresses) is especially relevant. Thus, the definition of the biochemical parameters of sperm at pathospermia is an actual problem of medical biochemistry and laboratory diagnostic. A cluster analysis was performed to determine the distribution of men (normozoospermic and with different semen abnormalities - oligo-, astheno-, oligoasthenzoospermia and leukocytospermia) by groups according to biochemical indices. To determine a degree of affinity between the individual biochemical indicators and distinguish the most important changes, the obtained results were analyzed by principal component analysis (PCA). Based on parameters of glutathion antioxidant system (GSG, GP, GR, GST), arginase/ NO-synthase system (cNOS, iNOS, arginase), membrane-bound ion transporting enzymes $\left(\mathrm{Na}^{+}, \mathrm{K}^{+}\right.$- and $\mathrm{Ca}^{2+}, \mathrm{Mg}^{2+}$-ATPase) and prooxidant manifestations (TBARS, GSSG), a cluster analysis of studied infertile male groups was performed. Normozoospermic males were the most distant from infertility men with leucocytospermia. However, the latter were involved in the formation of a subcluster which consisted of oligo-, astheno- and oligoasthenozoospermic groups. It is worth noting that oligo- and oligoashtenozoospermic males were the most related and formed a clear cluster based on the analyzed parameters. A usage of principal component analysis allowed quantitative proving a degree of affinity between changes of the individual investigated parameters under the conditions of pathospermia. By means of principal component analysis of the studied parameters a consistency of changes in oxidative manifestation (TBARS and GSSG content), and the activity of glutathione-S-transferase and ion-transporting systems of spermal membranes of asthenozoospermic samples were set up. In the oligozoospermic

() 2019 R. V. Fafula et al.; Published by the Ivan Franko National University of Lviv on behalf of Біологічні Студії / Studia Biologica. This is an Open Access article distributed under the terms of the Creative Commons Attribution License (http://www.budapestopenaccessinitiative.org/ and Creative Commons Attribution 4.0 License), which permits unrestricted reuse, distribution, and reproduction in any medium, provided the original work is properly cited.

ISSN 1996-4536 (print) • ISSN 2311-0783 (on-line) • Біологічні Студії / Studia Biologica • 2019 • Том 13/№1 • С. 39-50 
samples the closest relations between the activity of the ion-transporting systems of the spermal membranes and the content of the lipoperoxidation products were detected.

Keywords: male infertility, spermatozoa, oligozoospermia, asthenozoospermia, leukocytospermia

\section{INTRODUCTION}

Preservation of the reproductive health of the population is an actual socio-demographic and medical-biological problem not only in Ukraine, but also in a majority of developed countries. According to various studies the fraction of male infertility in structure of overall infertility is more than $40-50 \%$ and has a tendency to increase [14]. Elucidation of patterns of functions of male germ cells plays a crucial role in reproduction (deterioration of environmental conditions, psychological stresses) and is of topical relevance in modern conditions. Thus, a selection of the biochemical parameters of sperm cells under pathospermia is an actual problem of modern medical biochemistry, and laboratory diagnostics.

In previous studies, we have shown that pathospermia was associated with the development of oxidative stress, expressed as an increase in the thiobarbituric acid reactive substances (TBARS) level in sperm cells of the infertile men and the inverse correlation between TBARS level and spermatozoa concentration in the ejaculate and their motility [4]. It was found that in sperm of infertile men with various forms of semen abnormalities the activity of constitutive isoforms of NO-synthase (cNOS) and arginase were suppressed and the activity of inducible form (iNOS) was increased compensatory [2]. This indicates the hypeproduction of $\mathrm{NO}$. Inhibition of ouabainensitive $\mathrm{Na}^{+}, \mathrm{K}^{+}-$ ATPase activity in spermatozoa of the infertile men in all forms of pathospermia and decreased activity of tapsigargin-sensitive (ERCA) and tapsigargine-insensitive (PMCA) $\mathrm{Ca}^{2+}, \mathrm{Mg}^{2+}$-ATPase compared to fertile men was detected. However, $\mathrm{Ca}^{2+}, \mathrm{Mg}^{2+}$-ATPase activity tended to an increase in patients with oligozoospermia [9].

In most cases, pathobiochemical indices correlate with each other, as they are a result of specific measurements of certain integral characteristics. The variability of indices according to their values in normal physiological state reflects a severity of the pathological process and potency of the protective (compensatory) systems. It is due to influence of a huge amount of complex of characteristics. Therefore, the actual task is to identify various groups of the infertile men according to the biochemical parameters and determine a degree of relationships between the individual (pathological) biochemical indices and find out the most significant changes.

\section{MATERIALS AND METHODS}

For analysis, the results of our previous studies were used performed on sperm cells of the infertile men with different forms of semen abnormalities [2-4, 9]. The data of 56 men who passed from January 2014 to April 2017 a primary infertility survey in a consultative polyclinics of Lviv regional clinical hospital were analyzed. The inclusion criteria: 21-39 age, infertility for 1-10 years in marriage, male factor of infertility, evident oligozoospermia and/or asthenozoospermia. The exclusion criteria: the infertility in marriage for more than 10 years, azoospermia, excessive use of alcohol and influence of harmful physical and chemical factors during the diagnostic and treatment measures.

ISSN 1996-4536 (print) • ISSN 2311-0783 (on-line) • Біологічні Студії / Studia Biologica • 2019 • Том 13/№1 • С. 39-50 
In the analyzed experiments, all patients were divided into 4 groups: patients with oligozoospermia (OI), asthenozoospermia (Ast), oligoasthenozoospermia (OIAst) and leukocytospermia (Leu). The control group consisted of 20 somatically healthy men with a preserved fertility, normozoospermia $(\mathrm{N})$ and proven paternity.

To determine a degree of affinity between the studied groups of patients, a cluster analysis was performed using a complete linkage method, based on a certain level of similarity of an object with any other to form a cluster. The obtained results were committed to a multi-factor analysis to determine mutual dependencies of the variables and define the most important of them. Namely, principal component analysis was based on a transformation of certain sequence of investigated variables into another sequence of variables that are linear combinations of the initial variables. The analysis of parameters was carried out using a computer program Statistica v 10.0.

\section{RESULTS AND DISCUSSION}

Our former $[2-4,9]$ indicate a direction of changes in the biochemical parameters in sperm cells of the infertile men with various forms of semen abnormalities, although it is often a question of combining these forms according to certain criteria. It is known that cluster analysis allows grouping different studied groups at the same values of indices. Ordering of the recieved clusters and their affinity to each other allow one to visualize the homogeneous groups (clusters).

A cluster analysis was performed based on the indices of glutathione system of antioxidant defense (GSG, GP, GR, GST), arginase/NO-synthase system (cNOS, iNOS, arginase), membrane-bound ion transporting enzymes $\left(\mathrm{Na}^{+}, \mathrm{K}^{+}-\right.$and $\mathrm{Ca}^{2+}, \mathrm{Mg}^{2+}$-ATPase) and indices of oxidative manifestations (TBARS, GSSG) (Fig. 1). One can see from the results of our study, that the biochemical indices formed two separate cluster distant by the Euclidean distances. The normozoospermic men $(\mathrm{N})$ were the most distant from the infertility men with the leucocytospermia (Leu). However, the latter were involved in a formation of a sub-cluster consisting of oligo- (OI), astheno- (Ast) and oligoasthenozoospermic (OIAst) groups. It should be noted that the oligo- and oligoasthenozoospermic samples were the most related and formed a clear cluster based on the analyzed parameters.

To reveal biochemical relationships between the studied groups in more detail, a cluster analysis was performed separately for each of the components, namely the enzymatic (Fig. 2A) and the non-enzymatic component (Fig. 2B) of the glutathione antioxidant system, the arginase/NO-synthase system (Fig. $2 \mathrm{C}$ ), membrane-bound iontransporting enzymes (Fig. 2D) and the oxidative manifestations (Fig. 2E).

As one can see from the presented dendrograms of affinity for the values of the activities of arginase/NO-synthase (Fig. 2C) and membrane-bound ion transporting enzymes (Fig. 2D) based on the Euclidean distance and distance between classes, the obtained clusters were similar to the dendrogram of affinity by all studied biochemical indices. By the values of indices of the enzymatic components of the glutathione system the dendrogram of affinity (Fig. $2 A$ ) forms the same clusters, but the distance between them is an order of magnitude lower than the dendrogram of the affinity by all studied biochemical pathobiochemical indices.

The dendrogram of the affinity according to indices of the non-enzymatic component of the glutathione system and oxidative manifestations forms other clusters. As shown

ISSN 1996-4536 (print) • ISSN 2311-0783 (on-line) • Біологічні Студії / Studia Biologica • 2019 • Том 13/№1 • С. 39-50 


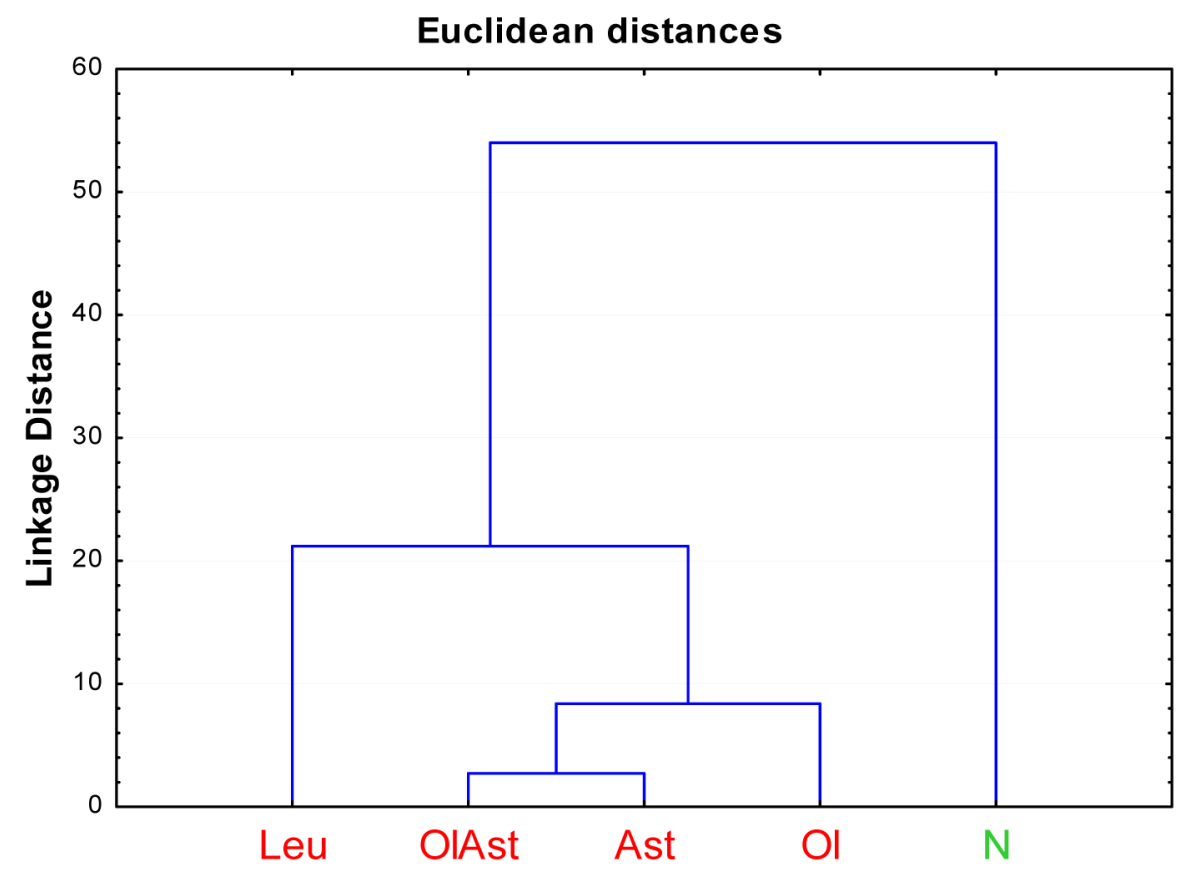

Fig. 1. Dendrogram of the relationship of indices in sperm cells of the normo- and pathozoospermic men (by all biochemical indices)

Hereinafter: N - normozoospermia; OI - oligozoospermia; Ast - asthenozoospermia; OIAst - oligoasthenzoospermia; Leu - leukocytospermia

Рис. 1. Дендрограма спорідненості нормо- та патозооспермічних чоловіків (за сукупністю всіх біохімічних показників)

Примітка: Тут і надалі N - нормозооспермія; Ol - олігозооспермія; Ast - астенозооспермія; OIAst - олігоастенозооспермія; Leu - лейкоцитоспермія

in the GSH / GSSG affinity dendrogram (Fig. 2B), fertile men with normozoospermia and infertile with leukocytospermia form a common cluster that is distant from another cluster formed by the oligo-, astheno- and oligoasthenozoospermic men. As a result of this analysis, it can be stated that GSH / GSSG system status in the leukocytospermic samples does not undergo significant changes, since this group of patients was in a single cluster with the fertile normozoospermic men. The results are confirmed by data from other researchers who found that maintaining of GSH / GSSG homeostasis in spermatozoa of the infertile men with an infectious factor was associated with a "sparing effect" caused by other non-enzymatic antioxidants, in particular vitamin C [10]. Similar distribution by clusters was obtained by indices of the oxidative manifestations (Fig. $2 E$ ).

In order to find out a degree of the affinity between the characteristics of the glutathione system of antioxidant defense, the arginase / NO-synthase system, membranebound ion transporting enzymes and oxidative manifestations in the normo- and astheno- / oligozoospermic samples (which are the most common forms of semen abnormalities), the results were processed using factor analysis.

One can see from Fig. 3, that the studied biochemical indices of the asthenozoospermic samples belong to two main components (determinant) with a probability of $40.0 \%$.

ISSN 1996-4536 (print) • ISSN 2311-0783 (on-line) • Біологічні Студії / Studia Biologica • 2019 • Том 13/№1 • С. 39-50 
The clusters of indices presented on Fig. 1 show a consistency of the oxidative manifestations (TBARS and GSSG) in sperm cells obtained from men with asthenozoospermia. In this case, the activity of enzymes and the content of the non-enzymatic component of the glutathione system of antioxidant defense in the astenozoospermic samples were not interrelated and with the parameters of the oxidative manifestations.
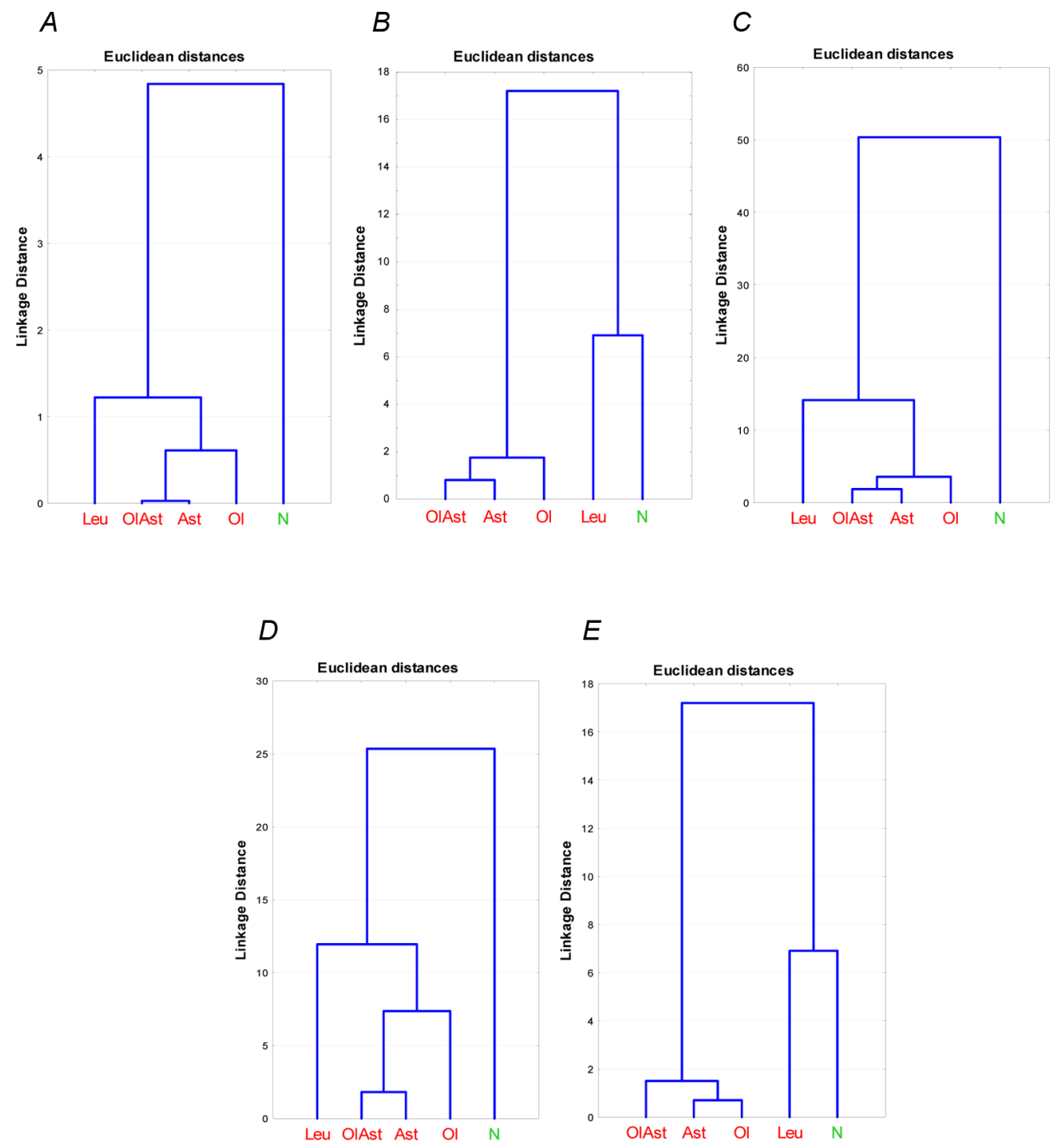

Fig. 2. Dendrogram of the relationship of indices in sperm cells of the normo- and pathozoospermic men (by separate biochemical indices)

Рис. 2. Дендрограма спорідненості нормо- та патозооспермічних чоловіків (за окремими біохімічними показниками) 
A consistency of changes in such parameters as the activity of ion transporting systems of spermal membranes $\left(\mathrm{Na}^{+}, \mathrm{K}^{+}-\right.$and $\left.\mathrm{Ca}^{2+}, \mathrm{Mg}^{2+}-\mathrm{ATPase}\right)$ and glutathione-Stransferase activity which form a joint cluster was also noted. Other studied indices by a location relative to factor 1 and factor 2 are separated from the above mentioned clusters. Changes in ATPase activity of plasma membranes of spermatozoa are factors that determine most of the values of the first two main components of the presented model (since these indices are the most distant from the origin of the coordinate system).

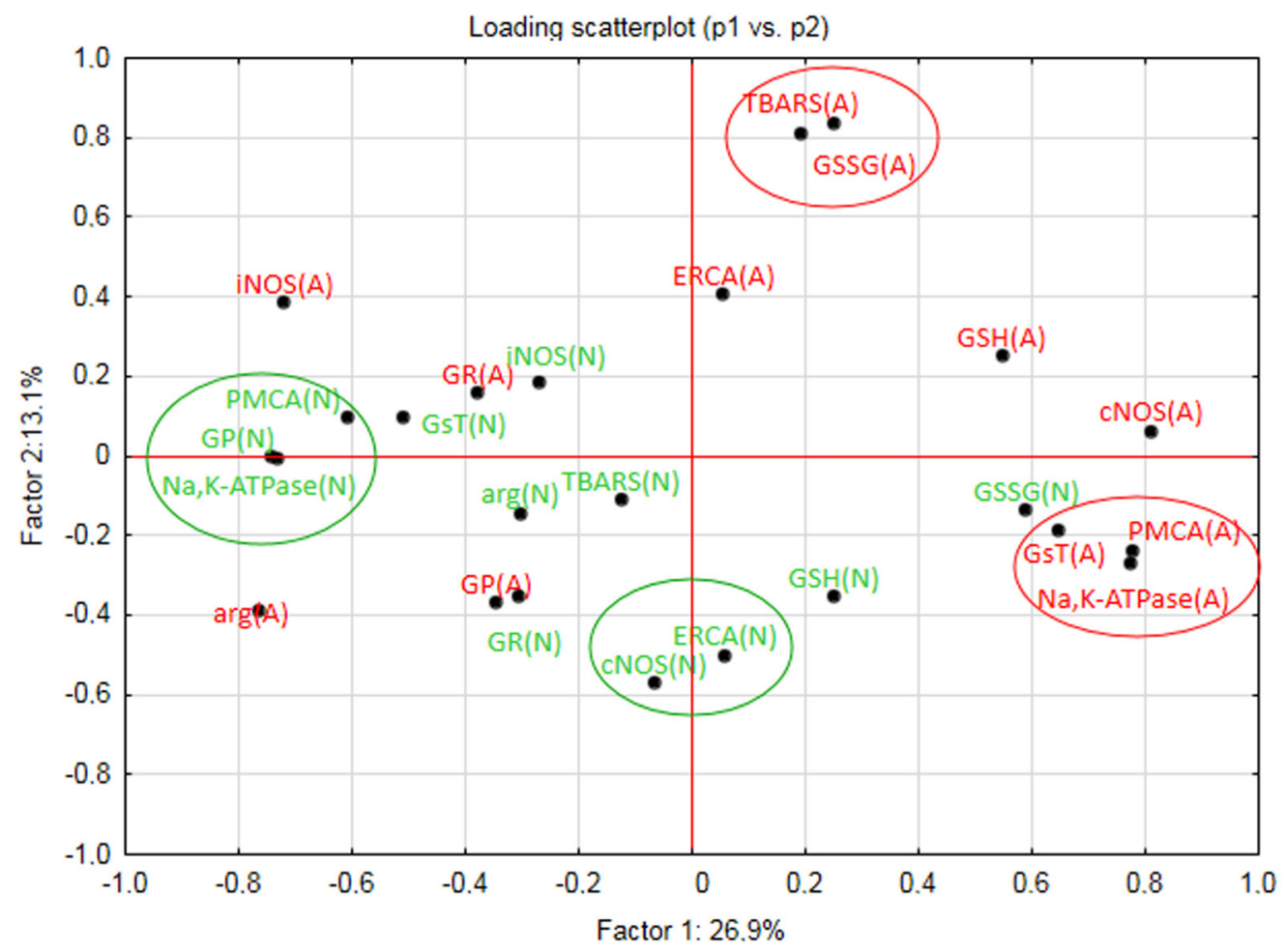

Fig. 3. Resuts of factor analysis (principal component analysis) of the biochemical indices in sperm cells obtained from men with the normo- $(\mathrm{N})$ and asthenozoospermia $(\mathrm{A})$ by all biochemical indices

Рис. 3. Факторний аналіз (метод головних компонент) сукупності біохімічних показників сперматозоїдів нормо- (N) і астенозооспермічних (А) чоловіків

Factor analysis of the biochemical indices of spermatozoa obtained from the infertile men with oligozoospermia (by all biochemical indices) revealed a slightly different dependence (Fig. 4). So, cluster is formed by the ion-transporting ATP-hydrolases and TBARS (somewhat remotely) that are mostly determined by two main components (since they are the most distant from the origin of the coordinate system). Also, the inversely related coherence of GSH / GSSG indices are remarkable.

It is known that increasing of the level of lipoperoxidation processes belongs to key pathochemical processes which are the basis of the development of sperm dysfunc-

ISSN 1996-4536 (print) • ISSN 2311-0783 (on-line) • Біологічні Студії / Studia Biologica • 2019 • Том 13/№1 • С. 39-50 
tion [1]. An appearance and accumulation of the oxidative damages (in the form of products of lipoperoxidation) arises as a result of constant generation of the reactive oxygen species (ROS) and leads to a violation of the antioxidant-antioxidant balance in cells. ROS cause an oxidative stress and damage the structure of proteins, nucleic acids and other bio(macro)molecules [19]. High sensitivity of sperm cells to the oxidative stress is due to high content of the polyunsaturated fatty acids in sperm membranes. Under the conditions of pathospermia, the prooxidant-antioxidant balance is displaced towards the uncontrolled generation of ROS, that leads to development of the oxidative stress [20]. According to high reactivity of ROS and, therefore, their insignificant life expectancy, their activity is estimated by the content of products of lipoperoxidation in addition to direct methods of their registration. It is known that TBARS level is an indicator of the intensity of lipoperoxidation processes in cells and the marker of endogenous intoxication. Besides TBARS, GSSG is also an indicator of the oxidative stress. In conditions of asthenozoospermia, the coordination of these indices of oxidative manifestations in spermatozoa was noted.

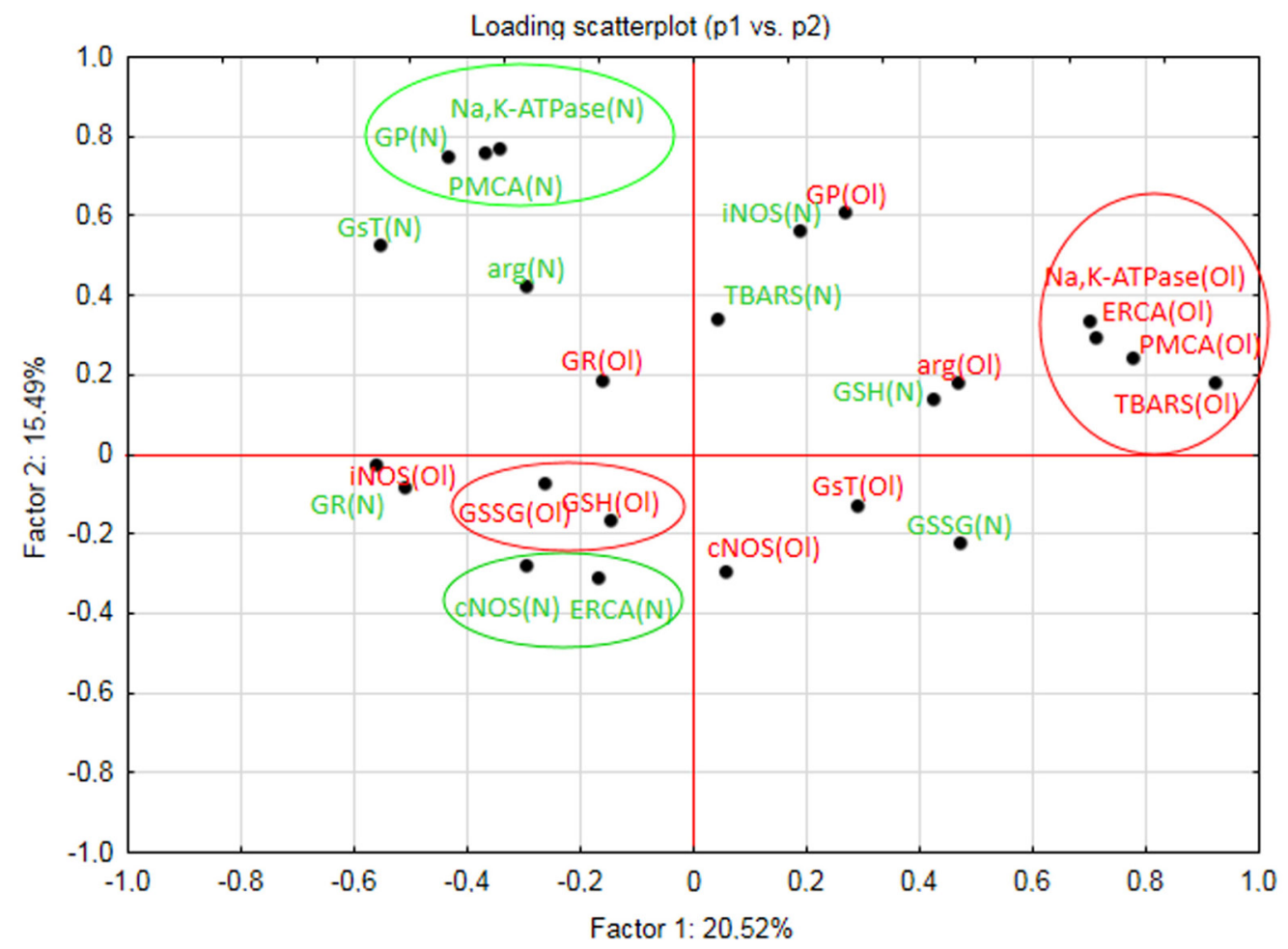

Fig. 4. Resuts of factor analysis (principal component analysis) of the biochemical indices in sperm cells obtained from men with normo- $(\mathrm{N})$ and oligozoospermia $(\mathrm{O})$

Рис. 4. Факторний аналіз (метод головних компонент) сукупності біохімічних показників сперматозоїдів нормо- (N) та олігозооспермічних (OІ) чоловіків

In addition to ROS, an important role in the development of the oxidative stress belongs to reactive forms of nitrogen, in particular, nitric (II) oxide (NO). It is known that

ISSN 1996-4536 (print) • ISSN 2311-0783 (on-line) • Біологічні Студії / Studia Biologica • 2019 • Том 13/№1 • С. 39-50 
NO plays a leading role in regulation of a wide range of biochemical processes and physiological functions in a cell (organism). On the other hand, this biomolecule has free radical and cytotoxic (at high concentrations) properties for the pathological conditions [21]. NO takes part in a reaction with other molecules and forms stable radicals, in particular peroxynitrite $\left(\mathrm{ONOO}^{-}\right)$, and also initiates processes of nitration of amino acids and proteins $[13,16]$. NO biosynthesis is carried out with L-arginine, that suggests its precursor with participation of the NO-synthases. They use $\mathrm{O}_{2}$ and NADPH as substrates of the reaction and catalyze two-stage oxidative transformation of L-arginine to $\mathrm{NO}$ and L-citrulline. iNOS is not expressed under the physiological norm, and its expression is induced by the proinflammatory factors, in particular, bacterial lipopolysaccharides and proinflammatory cytokines activated by the macrophages. It is known that this NOS isoform provides NO biosynthesis at concentrations that are several times higher than cNOS which is characteristic for the pathophysiological states [18]. With functioning of NOS, an arginase is closely related. Arginase hydrolytically cleaves L-arginine into L-ornitine and urea. Arginase can affect the NO biosynthesis in cells due to its competition with NOS for common substrate (L-arginine) [12]. We have found that in normozoospermic samples the state of NO-synthase / arginase system was characterized by the domination of the cNOS activity that ensures NO synthesis of the physiological amount. Under semen abnormalities, the redistribution of activities in NOS system with their shift towards the $\mathrm{Ca}^{2+}$-independent iNOS was revealed. This indicates dysmetabolic changes in NO biosynthesis, namely its hyperproduction [2]. According to the results of factor analysis, none of indices of this system form a cluster with other biochemical indices in the pathozoospermic samples. These data might be explained by the fact that in addition to the enzymatic biosynthesis of NO with the participation of NOS, there is a biosynthesis of NO through reduction from the nitrates or nitrites. Such mechanism of NO biosynthesis is peculiar for the pathological states characterized by a decrease in medium $\mathrm{pH}$ [15]. In the normozoospermic samples, a consistency of $\mathrm{Ca}^{2+}$ dependent cNOS and tapsigargin-sensitive $\mathrm{Ca}^{2+}, \mathrm{Mg}^{2+}$-ATPase which pumps an excess of the cytosolic $\mathrm{Ca}^{2+}$ in the intracellular $\mathrm{Ca}^{2+}$-stores was noted.

The maintenance of the prooxidant-antioxidant balance is provided by the antioxidant enzyme and non-enzymatic cell systems. The biological role of antioxidant systems is in their ability to interrupt lipoperoxidation chain, inactivate radicals and convert them into low reactive products [7]. The anti-radical and anti-peroxide protection belong to a reduced glutathione (GSH) and associated enzymes that form glutathione antioxidant system particularly important in the maintaining of cell vitality. A depletion of the glutathione system leads to cytotoxic and destructive changes [6]. To assess the state of the antioxidant defense adequately, the ratio of GSH / GSSG (or glutathione index) as an indicator of the oxidation-reducing thiol-disulfide equilibrium of the glutathione redox system [11] is used. The GSH / GSSG equilibrium is important for normal functioning of the cell and provides the anti-peroxidant protection. Reducing GSH content indicates a disturbance violation of the compensatory mechanisms of antioxidant cell defense. It is known that GSH is a sensitive target for effect of the prooxidants, and a decrease in its content is accompanied by an oxidative stress $[5,17]$. According to the results of factor analysis, none of indices of glutathione antioxidant system have formed a cluster with other biochemical indices. In addition to the glutathione system, other antioxidant systems such as superoxide dismutase are present in sperm cells [22].

ISSN 1996-4536 (print) • ISSN 2311-0783 (on-line) • Біологічні Студії / Studia Biologica • 2019 • Том 13/№1 • С. 39-50 
In addition, glutathione systems are closely related to processes of the biochemical detoxification that are carried out with participation of the glutathione-S-transferase. According to the results of factor analysis, it was found that in the astenozoospermic samples GST activity formed one cluster together with ATP-dependent ion transporting enzymes. It is known that the processes of lipid peroxidation play an important role in functioning of the biological membranes, namely, in a renewal of their lipid components, regulation of physico-chemical properties of biomembranes [8]. The overwhelming majority of the pathophysiological changes are implemented at the membrane-cellular level. A peculiarity of these pathological states (membranopathies) is a disturbance of functioning of the biological membranes. The biomembranes are the first target for the effects of free radicals and toxic compounds. The membrane-bound components of the biomembranes acquire properties that are not characteristic for a physiological state of the cell.

In present study, there are certain limitations control group (normozoospermic men with a confirmed fertility) and pathozoospermic patients represent a heterogeneous population, with variations in spermogram parameters and history of the infertility. This study was conducted using a limited samples size. Therefore, it is important to confirm the obtained results with larger sample sizes and determine specificity of the disease (secretory or excretory form of infertility, varicocele, etc.). Nevertheless, the presented results are important for understanding not only a direction of change in patients with semen abnormalities, but also their affinity and dependence. A use of the multimarker approach has allowed to establish peculiarities of the pathobiochemical changes of sperm cells of patiens with different forms of the pathozoospermia.

\section{CONCLUSIONS}

By means of principal component analysis of the studied parameters, a consistency of changes in the oxidative manifestation (TBARS and GSSG content), activity of glutathione-S-transferase and ion-transporting systems of spermal membranes of the asthenozoospermic samples was set up. In the oligozoospermic samples, the closest relations between the activity of the ion-transporting systems of spermal membranes and content of the lipoperoxidation products was detected.

1. Colagar A.H., Karimi F., Jorsarae S.G. Correlation of sperm parameters with semen lipid peroxidation and total antioxidants levels in astheno- and oligoasheno- teratospermic men. Iran. Red. Crescent. Med. J., 2013; 15(9): 780-785.

[DOI: https://doi.org/10.5812/ircmj.6409]

2. Fafula R.V., lefremova U.P., Onufrovych O.K., Maksymyuk H.V., Besedina A.S., Nakonechnyi Io.A., Vorobets D.Z., Vorobets Z.D. Alterations in arginase-NO-synthase system of spermatozoa in human subjects with different fertility potential. Journal of Medical Biochemistry, 2018; 37: 1-7.

[DOI: https://doi.org/10.1515/jomb-2017-0049]

3. Fafula R.V., Onufrovych O.K., lefremova U.P., Melnyk O.V., Nakonechnyi I.A., Vorobets D.Z., Vorobets Z.D. Glutathione content in sperm cells of infertile men. Regul. Mech. Biosyst., 2017; 8(2): 157-161.

[DOI: https://doi.org/10.15421/021725]

ISSN 1996-4536 (print) • ISSN 2311-0783 (on-line) • Біологічні Студії / Studia Biologica • 2019 • Том 13/№1 • С. 39-50 
4. Fafula R.V., Onufrovych O.K., Vorobets D.Z., lefremova U.P., Vorobets Z.D. Glutathione antioxidant protection system in ejaculated spermatozoa of infertile men with different forms of pathospermia. Studia Biologica, 2017; 11(1): 17-24.

[DOI: https://doi.org/10.30970/sbi.1101.512]

5. Falfushynska H.I., Gnatyshyna L.L., Stoliar O.B., Nam Y.K. Various responses to copper and manganese exposure of Carassius auratus gibelio from two populations. Comp. Biochem. Physiol., 2011; 154(3): 242-253.

[DOI: https://doi.org/10.1016/j.cbpc.2011.06.001]

6. Kalinina E.V., Chernov N.N., Novichkova M.D. Role of glutathione, glutathione transferase, and glutaredoxin in regulation of redox-dependent processes. Biochemistry, 2014; 79(13): 1562-83.

[DOI: https://doi.org/10.1134/S0006297914130082]

7. Lityuga V.V., Andreychenko K.S. Investigation of the ultrasound effect of therapeutic intensities on the content of inflammatory markers and oxidative stress in plasma and erythrocytes of blood of rats at experimental inflammation of upper respiratory tract. Actual problems of transport medicine, 2011; 4(26): 115-124. (In Ukrainian)

8. Lushchak V.I., Bagnyukova T.V., Luzhna L.I. Indicators of oxidative stress. Lipids peroxides. Ukr. Biochem. J., 2006; 78(5): 113-119. (In Ukrainian)

9. Meskalo O.I., Fafula R.V., Lychkovskyj E.I., Vorobets Z.D. $\mathrm{Na}^{+}, \mathrm{K}^{+}-\mathrm{ATP}$ ase and $\mathrm{Ca}^{2+}, \mathrm{Mg}^{2+}$ ATPase activity in spermatozoa of infertile men with different forms of pathospermia. Studia Biologica, 2017; 11(2): 5-12. [DOI: https://doi.org/10.30970/sbi.1101.512].

10. Micheli L., Cerretani D., Collodel G., Menchiari A., Moltoni L., Fiaschi A.I., Moretti E. Evaluation of enzymatic and non-enzymatic antioxidants in seminal plasma of men with genitourinary infections, varicocele and idiopathic infertility. Andrology, 2016; 4(3): 456-464.

[DOI: https://doi.org/10.1111/andr.12181]

11. Mirończuk-Chodakowska I., Witkowska A.M., Zujko M.E. Endogenous non-enzymatic antioxidants in the human body. Adv Med Sci, 2018; 63(1): 68-78.

[DOI: https://doi.org/10.1016/j.advms.2017.05.005]

12. Morris S.M. Recent advances in arginine metabolism: roles and regulation of the arginases // Brit. J. Pharmacol., 2009; 157(6): 922-930.

[DOI: https://doi.org/10.1111/j.1476-5381.2009.00278.x]

13. Mosińska P., Salaga M., Fichna J. The role of oxidative stress in the pathophysiology of gastrointestinal disorders. Gastrointestinal tissue. Academic Press, 2017: 53-64.

14. Naz M., Kamal M. Classification, causes, diagnosis and treatment of male infertility: a review. Oriental Pharmacy and Experimental Medicine, 2017; 17(2): 89-109. [DOI: https://doi.org/10.1007/s13596-017-0269-7]

15. Osipov A.N., Borisenko G.G., Vladimirov Yu.A. The biological role of nitrosyl complexes of hemoproteins. Successes of biol. chemistry, 2007; 47: 259-292. (In Russian)

16. Pacher P., Beckman J.S., Liaudet L. Nitric oxide and peroxynitrite in health and disease. Physiol. Rev., 2007; 87(1): 315-424. [DOI: https://doi.org/10.1152/physrev.00029.2006]

17. Paital B., Panda S.K., Hati A.K., Mohanty B., Mohapatra M.K., Kanungo S., Chainy G.B. Longevity of animals under reactive oxygen species stress and disease susceptibility due to global warming. World J. Biol. Chem., 2016 Feb 26; 7(1): 110-127. [DOI: https://doi.org/10.4331/wjbc.v7.i1.110]

18. Pautz A., Art J., Hahn S., Nowag S., Voss C., Kleinert H. Regulation of the expression of inducible nitric oxide synthase. Nitric oxide, 2010; 23(2): 75-93.

[DOI: https://doi.org/10.1016/j.niox.2010.04.007]

ISSN 1996-4536 (print) • ISSN 2311-0783 (on-line) • Біологічні Студії / Studia Biologica • 2019 • Том 13/№1 • С. 39-50 
19. Valko M., Leibfritz D., Moncol J., Cronin M.T., Mazur M., Telser J. Free radicals and antioxidants in normal physiological functions and human disease. Int. J. Biochem. Cell. Biol., 2007; 39(1): 44-84.

[DOI: https://doi.org/10.1016/j.biocel.2006.07.001]

20. Wagner H., Cheng J.W., Ko E.Y. Role of reactive oxygen species in male infertility: An updated review of literature. Arab. J. Urol., 2018; 16(1): 35-43.

[DOI: https://doi.org/10.1016/j.aju.2017.11.001]

21. Weidinger A., Kozlov A.V. Biological activities of reactive oxygen and nitrogen species: oxidative stress versus signal transduction. Biomolecules, 2015; 5(2): 472-484. [DOI: https://doi.org/10.3390/biom5020472]

22. Yan L., Liu J., Wu S., Zhang S., Ji G., Gu A. Seminal superoxide dismutase activity and its relationship with semen quality and SOD gene polymorphism. J. Assist. Reprod. Genet., 2014; 31(5): 549-554.

[DOI: https://doi.org/10.1007/s10815-014-0215-2]

\title{
СПОРІДНЕНІСТЬ МІЖ ЗМІНАМИ ОСНОВНИХ БІОХІМІЧНИХ ПОКАЗНИКІВ У СПЕРМАТОЗОЇДАХ ІНФЕРТИЛЬНИХ ЧОЛОВІКІВ
}

\author{
Р. В. Фафула, З. Д. Воробець \\ Львівський національний медичний університет імені Данила Галицького \\ вул. Пекарська, 69, Львів 79010, Україна \\ e-mail: roman_fafula@ukr.net
}

3'ясування закономірностей функціонування чоловічих статевих клітин, які відіграють вирішальну роль у здійсненні репродуктивної функції, набуває особливої актуальності в сучасних умовах (екологічні та психологічні стреси). У зв'язку з цим вибір біохімічних показників сперматозоїдів під час дослідження патоспермій $є$ актуальною проблемою сучасної медичної біохімії, лабораторної діагностики та ін. Для виявлення розподілу досліджуваних груп чоловіків (нормозооспермічних і з різними формами патоспермій - оліго-, астено-, олігоастенозооспермічних і лейкоцитоспермічних) за низкою біохімічних параметрів проводили кластерний аналіз. Для з'ясування ступеня спорідненості між окремими біохімічними показниками та виокремлення найвагоміших змін одержані результати аналізували за допомогою методу головних компонент (детермінант, PCA). На основі показників глутатіонової ланки антиоксидантного захисту (GSG, GP, GR, GST), аргіназо-NO-синтазної системи (cNOS, iNOS, аргіназа), мембранозв'язаних йон-транспортувальних ензимів ( $\mathrm{Na}^{+}, \mathrm{K}^{+}-$ та $\mathrm{Ca}^{2+}, \mathrm{Mg}^{2+}$-АTФ-аза) та показників прооксидантних проявів (TBARS, GSSG) проведено кластерний аналіз досліджуваних груп чоловіків. Нормозооспермічні чоловіки були найбільш віддалені від інфертильних чоловіків із лейкоцитоспермією. Однак останні були залучені до фрормування субкластера, який складався з оліго-, астеной олігоастенозооспермічних груп. Варто зазначити, що оліго- й олігоастенозооспермічні чоловіки були найбільш споріднені та формували чіткий кластер на основі аналізованих параметрів. Використання методу головних детермінант дало змогу кількісно довести ступінь спорідненості між змінами окремих досліджуваних показників за умов патоспермії. За допомогою методу головних детермінант усіх досліджуваних показників встановлено узгодженість змін показників прооксидантних

ISSN 1996-4536 (print) • ISSN 2311-0783 (on-line) • Біологічні Студії / Studia Biologica • 2019 • Том 13/№1 • С. 39-50 
проявів (TBARS і GSSG), активності глутатіон-S-трансферази та йон-транспортувальних систем спермальних мембран у астенозооспермічних зразках. В олігозооспермічних зразках найтісніший зв'язок виявлено між активністю йон-транспортувальних систем спермальних мембран і вмістом продуктів ліпопероксидації.

Ключові слова: чоловіче непліддя, сперматозоїди, олігозооспермія, астенозооспермія, лейкоцитоспермія

Одержано: 29.03.2019 